\title{
Correction to: Identifying resting locations of a small elusive forest carnivore using a two-stage model accounting for GPS measurement error and hidden behavioral states
}

Dalton J. Hance ${ }^{1 *}$, Katie M. Moriarty ${ }^{2}$, Bruce A. Hollen ${ }^{3}$ and Russell W. Perry ${ }^{1}$

Correction to: Mov Ecol 9, 17 (2021)

https://doi.org/10.1186/s40462-021-00256-8

Following publication of the original article [1], the authors flagged that due to a typesetting mistake, the Additional file 2 (a zip file containing the data and code necessary to replicate the analysis) was omitted from the article.

Additional file 2 is attached to this Correction and has been added to the original article. The publisher apologises to the authors and readers for the inconvenience caused by this omission.

\section{Supplementary Information}

The online version contains supplementary material available at https://doi. org/10.1186/s40462-021-00262-w.

Additional file 2. Complete $\mathrm{R}$ and Stan code for reproducing the statistical analyses in this manuscript.

\section{Author details}

'US Geological Survey, Western Fisheries Research Center, Columbia River Research Laboratory, Cook, WA 98605, USA. ${ }^{2}$ National Council for Air and Stream Improvement, Inc., Corvallis, OR, USA. ${ }^{3}$ USDI Bureau of Land Management State Office, Portland, OR, USA.

The original article can be found online at https://doi.org/10.1186/s40462 021-00256-8.

* Correspondence: dhance@usgs.gov

'US Geological Survey, Western Fisheries Research Center, Columbia River Research Laboratory, Cook, WA 98605, USA

Full list of author information is available at the end of the article
Published online: 23 April 2021

\section{Reference}

1. Hance DJ, et al. Identifying resting locations of a small elusive forest carnivore using a two-stage model accounting for GPS measurement error and hidden behavioral states. Mov Ecol. 2021;9:17 https://doi.org/10.1186/s4 0462-021-00256-8

C C The Author(s). 2021 Open Access This article is licensed under a Creative Commons Attribution 4.0 International License, which permits use, sharing, adaptation, distribution and reproduction in any medium or format, as long as you give appropriate credit to the original author(s) and the source, provide a link to the Creative Commons licence, and indicate if changes were made. The images or other third party material in this article are included in the article's Creative Commons licence, unless indicated otherwise in a credit line to the material. If material is not included in the article's Creative Commons licence and your intended use is not permitted by statutory regulation or exceeds the permitted use, you will need to obtain permission directly from the copyright holder. To view a copy of this licence, visit http://creativecommons.org/licenses/by/4.0/ The Creative Commons Public Domain Dedication waiver (http://creativecommons.org/publicdomain/zero/1.0/) applies to the data made available in this article, unless otherwise stated in a credit line to the data. 